\title{
INTERVENSI PSIKOLOGI DALAM PENANGANAN KASUS UNDERCHIEVER
}

Oleh :

Beti Malia Rahma Hidayati

\section{Abstrak:}

Anak yang berprestasi rendah dibandingkan tingkat kecerdasan yang dimilikinya disebut dengan underachievement. Dalam penyelesaian kasus ini, dilakukan asesmen untuk pengambilan keputusan tentang pengetahuan dan kemampuan subjek. Asesmen yang digunakan diantaranya adalah: wawancara, observasi, tes psikologi (BINET dan grafis). Setelah diperoleh data, maka inilah perilaku yang diklasifikasikan akan dikurangi dan ditingkatkan. Adapun perilaku yang akan dikurangi yaitu keluar dari bangku saat proses balajarmengajar, bersuara keras saat proses belajar-mengajar, dan mendapatkan uang saat akan atau setelah melakukan hal yang baik. Sedangkan perilaku yang akan ditingkatkan yaitu mengerjakan tugas secara mandiri dengan tuntas, membawa buku sesuai jadwal, dan melakukan sesuatu yang baik tanpa imbalan uang.

Adapun intervensi yang dilakukan yaitu: konseling individual, token ekonomi, aversif, dan positif parenting skill. Berdasarkan hasil intervensi yang dilakukan, Subjek telah mengalami perubahan yang positif. Evaluasi intervensi dilakukan guna mendapatkan informasi penilaian. Efektif tidaknya intervensi tersebut dalam penanganan kasus underchiever menjadi materi penting untuk program tindak lanjut dan acuan penanganan kasus yang serupa. Program intervensi dalam penanganan kasus underchiever ini telah selesai, untuk mendapatkan hasil yang maksimal perlu adanya dukungan dan partisipasi yang baik dari berbagai pihak. Termasuk untuk melaksanakan saran-saran yang diajukan guna mendapatkan hasil intervensi yang maksimal dalam penanganan kasus underchiever.

\section{Pendahuluan}

Pendidikan dasar bertujuan untuk meletakkan dasar kecerdasan, pengetahuan, kepribadian, akhlak mulia, serta keterampilan untuk hidup mandiri dan mengikuti pendidikan lebih lanjut (PP. No. 19 tahun 2005, pasal

\footnotetext{
* IAI Tribakti Kediri.
} 
26). Pembelajaran merupakan salah satu kegiatan pokok setiap madrasah. ${ }^{1}$ Madrasah sebagai tempat menuntut ilmu, tidak hanya mengajarkan berbagai ilmu pengetahuan saja kepada siswa, tetapi juga mendidik dan mengarahkan tingkah laku siswa dari yang kurang baik menjadi yang lebih baik. ${ }^{2}$ Sehingga, madrasah harus sebijak mungkin memfasilitasi proses belajar mengajar. Termasuk memberikan layanan menyelesaian dalam kasus-kasus pendidikan siswa-siswinya.

Sementara itu, Slameto menyatakan bahwa ada dua faktor yang mempengaruhi keberhasilan siswa dalam belajar yaitu faktor intern (berasal dari dalam diri siswa) dan faktor ekstern (berasal dari luar diri siswa). Faktor intern diantaranya yaitu: faktor jasmaniah (kesehatan, cacat tubuh), faktor psikologis (intelegensi, perhatian, minat, bakat, motif, keterampilan belajar, kematangan, dan kesiapan), dan faktor kelelahan (jasmani dan rohani). Sedangkan faktor ekstern atau faktor yang berasal dari luar diri individu seperti lingkungan, keluarga, madrasah, dan masyarakat. ${ }^{3}$

Keluarga merupakan lingkungan sosial pertama bagi anak. Orangtua diharapkan dapat membantu anak dalam menyesuaikan diri dengan lingkungan untuk mengatasi masalah secara realistik dan simpati. Di sisi lain, keluarga sering kali menjadi sumber konflik. Salah satunya adalah perceraian orangtua. Ketika perceraian terjadi, anak akan menjadi korban utama. Orangtua yang bercerai harus tetap memikirkan bagaimana membantu anak untuk mengatasi dampak dari perpisahan orangtuanya. Perceraian orangtua dianggap sebagai salah satu penyebab utama kegagalan masa depan anak.

Sebuah penelitian dari studi kasus di Desa Pengauban Kecamatan Lelea Kabupaten Indramayu (Ulpatusalicha, UIN Sunan Kalijaga Yogyakarta, 2009) diperoleh hasil bahwa perceraian orangtua berdampak negatif pada kehidupan anak, namun ada pula anak yang mampu mengatasi dampak tersebut, itu dikarenakan faktor dari individu dan latar belakang orangtua yang mampu memberi penjelasan, dan harapan yang timbul dari anak-anak korban perceraian.

${ }^{1}$ Supratiknya dan Titik Kristiyani. Efektifitas Metode Problem-Based Learning dalam Pembelajaran Mata Kuliah Teori Psikologi Kepribadian II. Jurnal Psikologi. Volume 33, No.1, ISSN: 0215-8884. Fakultas Psikologi Yniversitas Gadjah Mada. Hal: 1

${ }_{2}$ Ridho Illahi, Syahniar, Indra Ibrahim. Faktor yang Mempengaruhi Pelanggaran Disiplin Siswa dan Implementasinya Terhadap Layanan Bimbingan dan Konseling. Konselor, Jurnal Ilmiah Konseling. Volume 2, Nomor 2, Juni 2013.Hal.20

${ }^{3}$ Ibid. 
Perpisahan bukan hanya satu-satunya peristiwa bagi anak. Anak biasanya dapat menyesuaikan diri dalam perubahan praktis seperti pindah rumah, madrasah, dapat diterima dengan mudah. Kesulitan yang lebih dalam yang timbul adalah perubahan emosi yang tidak terlihat (dalam Mitchell, 1992). ${ }^{4}$

Piaget maupun Kohlberg sependapat bahwa orang tua mempunyai peran besar bagi pembentukan dan perkembangan moral anak. Tanggung jawab orang tua untuk menanamkan nilai-nilai moral, etika, budi pekerti bahkan nilai religius sejak dini akan membekas didalam hati sanubarinya. John Locke mengibaratkan bahwa hati dan otak pada diri seorang anak masih berupa lembaran kertas kosong putih bersih. Lembaran itu masih bersifat murni, sehingga apapun yang terisi di atas lembaran itu sangat tergantung dari orang tua, demikian pula pendidikan yang telah diterima sejak masa kanak-kanak akan mempengaruhi pola pikir dan perilaku dalam diri anak (dalam Dariyo, 2004). ${ }^{5}$

Dalam kasus ini, ditemukan salah satu siswa kelas IIIA memiliki prestasi belajar rendah. Semua guru yang pernah mengajarnya menyatakan demikian. Hingga muncul anggapan bahwa siswa tersebut, sebut saja "YRW" memang mempunyai kemampuan rendah dan rawan untuk tidak naik kelas sejak kelas satu. YRW sulit untuk dikendalikan dan cenderung melakukan hal-hal sesuai keinginannya. Didalam kelas sering kali membuat gaduh dan tugas-tugasnya sangat tertinggal dari teman kelas yang lain. Ia juga sering tidak membawa buku sesuai dengan jadwal, sehingga menjadi alasan jika ditanyakan PR atau diberikan tugas. Kondisinya yang berasal dari keluarga bercerai, dianggap menjadi faktor munculnya perilaku negatif tersebut di dalam kelas. Dalam hal ini, faktor intern dan ekstern sama-sama berperan untuk keberhasilan proses pembelajaran. Namun, hasil tes intelegensi menunjukkan bahwa kemampuan umum YRW berada pada taraf rata-rata atas. Lebih rinci, identitas diri YRW dapat dilihat pada tabel 1.

\section{Tabel 1: Identitas Diri Subjek}

\begin{tabular}{|l|l|}
\hline Nama & $:$ YRW (inisial) \\
Jenis Kelamin & : Laki-laki \\
Lahir & $:$ 15 Januari 2006 \\
\hline
\end{tabular}

${ }^{4}$ Rida Nurhayanti. Dwi Novotasari, dan Natalia. Tipe Pola Asuh Orang Tua yang Berhubungan dengan Perilaku Bullying di SMA Kabupaten Semarang. Jurnal Keperawatan Jiwa. Volume 1. No. 1. Mei 2013; hal: 51.

${ }^{5}$ Ibid. 


\begin{tabular}{|l|l|l|l|}
\hline $\begin{array}{l}\text { Umur } \\
\text { Agama } \\
\text { Anak ke }\end{array}$ & \begin{tabular}{l}
$:$ 8 tahun \\
$:$ Islam \\
\multicolumn{1}{|c|}{ 1 dari 1 bersaudara (kandung) } \\
mempunyai 1 saudara dari pernikahan ibunya yang ke 2
\end{tabular} \\
\hline \multicolumn{1}{|c|}{ Identitas } & \multicolumn{1}{|c|}{ Abah } & \multicolumn{1}{|c|}{ Wali } \\
\hline Nama & AW (inisial) & Ah (inisial) & Yh (inisial) \\
Umur & 37 tahun & 32 tahun & 55 tahun \\
Agama & Islam & Islam & Islam \\
Pendidikan & SMA & SMP \\
Pekerjaan & Sopir & Ibumah & Pelihara kambing \\
& & & \\
\hline
\end{tabular}

\section{Underachievement}

Anak yang berprestasi rendah dibandingkan tingkat kecerdasan yang dimilikinya disebut dengan underachievement. Definisi lain dari underachievement adalah sebagai ketidakmampuan untuk menampilkan prestasi sesuai dengan usia atau bakat yang dimiliki. Namun demikian, underachievers tidak memiliki karakteristik yang sama. Underachievement muncul dalam bentuk yang luas dan beragam. Dalam hal ini, faktor intern dan ekstern yang menjadi penyebab munculnya permasalahan atau penunjang munculnya permasalahan akan diatasi dengan rancangan intervensi.

Anak dengan bakat intelektual adalah anak yang sangat sensitif, sehingga perlakuan terhadapnya yang dianggap tidak adil dapat membawanya pada kemarahan dan agresivitas, kefrustasian dan depresi, bahkan bisa berlanjut pada masalah psikologis. ${ }^{6}$ Terbukti di dalam kelas, YRW beberapa kali terlibat pertengkaran dengan temannya dan beberapa kali pula marah-marah. Namun, YRW tidak sepenuhnya merasa bersalah, sebab ia memaknai perilakunya sebagai upaya pembelaan diri dan atau terkadang untuk membantu teman yang lain, bahkan membantu gurunya. Reis \& McMoah mengemukakan bahwa underachiever merupakan kesenjangan akut antara potensi prestasi dan prestasi yang diraih (dalam Tarmidi, 2008). YRW yang memiliki kapasistas intelegensi pada taraf rata-rata atas, ternyata selalu mendapat peringkat akhir, bahkan rawan untuk tidak naik kelas. Disini terlihat ada kesenjangan antara potensi yang dimilikinya dengan prestasi yang diraihnya di sekolah.

${ }^{6}$ Zainul Anwar. 2013. Analisis Underchiever pada Siswa Akselerasi. Fakultas Psikologi Universitas Muhammadiyah Malang. Jurnal Online Psikologi. Vol.01 No.01, Tahun 2013. ISSN: 2301-8259 
Menurut Whitemore terdapat enam faktor yang menyebabkan anak menjadi underachiever, dimana tiga faktor termasuk ke dalam karakteristik kepribadian dan tiga faktor lainnya merupakan kondisi lingkungan. ${ }^{7}$ Sedangkan menurut Rimm terdapat tiga faktor yang menyebabkan siswa menjadi underachiever, yaitu (1) faktor sekolah, (2) faktor rumah, dan faktorfaktor lainnya seperti faktor kepribadian dan adanya faktor gangguan belajar (Hawadi, 2004 dalam Zainul, 2013).

Menurut Clark ada beberapa karakeristik yang ditunjukan siswa underachiever, yaitu sebagai berikut:

$>$ Menunjukan prestasi yang berlawanan dengan harapan atau potensi yang dimilikinya.

$>$ Merasa tidak senang dengan sekolah atau gurunya dan cenderung bergabung dengan teman yang juga memiliki sikap negatif terhadap sekolah.

$>$ Kurang termotivasi untuk belajar, tidak mengerjakan tugas, sering mengantuk ketika belajar dan tidak tuntas dalam mengerjakan tugas.

$>$ Kurang mampu melakukan penyesuaian intelektual.

> Merasa kurang bersemangat, kurang tegas dan sering ribut di kelas.

$>$ Memiliki disiplin yang rendah, sering telat sekolah, enggan mengerjakan tugas, sering ribut, dan mudah terpengaruh.

$>$ Tidak memiliki hobi atau minat terhadap kegiatan untuk mengisi waktu luang.

$>$ Takut ujian dan berprestasi rendah.

Ciri-ciri tersebut juga terlihat pada YRW, namun sebenarnya ia masih bisa dibantu dengan kerjasama yang baik dari semua pihak, baik keluarga di rumah maupun guru disekolah agar berdampak positif bagi YRW dan memberikan jalan menuju perubahan yang lebih baik.

\section{Penyelesaian Kasus}

Kasus underachievement pada YRW, akan selesaikan sebagaimana sesuai prosedur penanganan masalah psikologis. Dalam hal ini, penyelesaian kasus yang dilakukan meliputi asesmen, intervensi, hingga evaluasi intervensi.

\footnotetext{
${ }^{7}$ Munandar U., 2009. Pengembangan kreativitas anak berbakat. Jakarta: Rineka
} Cipta. 


\section{Asesmen}

Asesmen merupakan proses pengumpulan informasi dari perilaku subjek yang digunakan sebagai dasar untuk pengambilan keputusan tentang pengetahuan dan kemampuan subjek tersebut. Dalam proses asesmen akan dilihat faktor pendorong perilaku target dari subjek, mulai anteseden (segala hal yang mencetus perilaku yang dipermasalahkan, situasi tertentu, dan kehadiran orang lain), respon (perilaku yang dipermasalahkan, baik dari segi frekuensinya, intentitasnya, ataupun lamanya), hingga konsekuen (akibat yang diperoleh setelah perilaku terjadi). Setelah diperoleh data akan diklasifikasikan perilaku yang mana akan dikurangi, ditingkatkan, atau tidak sesuai norma. Langkah berikutnya akan dilakukan kontrol untuk membuat situasi yang mendukung proses perubahan, menetapkan tujuan, metode, dan siapa saja yang berperan dalam proses penyelesaian kasus. Tahap terakhir akan dilakukan evaluasi keberhasilan proses, hasil, dan tindak lanjut.

Pendalaman permasalahan dilakukan dengan wawancara, yaitu metode pengumpulan data dengan jalan tanya jawab sepihak yang dikerjakan dengan sistematik dan berlandaskan kepada tujuan penyelidikan. Yang dimaksud dengan sepihak disini menerangkan perbedaan tingkat kepentingan antara kedua belah pihak. Wawancara ini bertujuan untuk pengumpulan data dan pengukuran psikologis. Wawancara dilakukan kepada guru kelas subjek, orang tua/ wali, dan terhadap subjek sendiri.

Selain wawancara, observasi juga dilakukan. Observasi merupakan suatu kegiatan dalam rangka mengumpulkan data yang berkaitan dengan masalah melalui proses pengamatan langsung di lapangan. Observasi merupakan tindakan memperhatikan secara akurat, mencatat fenomena yang muncul, dan mempertimbangkan hubungan antara aspek dan fenomena tersebut. Observasi digunakan untuk mendapatkan data tentang suatu masalah sehingga diperoleh pemahaman, serta sebagai alat pembuktian terhadap informasi atau keterangan yang di peroleh sebelumnya.

Observasi dilakukan dengan mengamati subjek secara langsung dan mencatat perilaku yang terlihat untuk digunakan sebagai data penunjang. Dalam observasi, dilakukan pengukuran frekuensi terjadinya perilaku target dalam periode tertentu. Dalam proses observasi juga dilakukan manipulasi kondisi, dimana akan dimunculkan "kondisi" untuk membuktikan kebenaran perilaku target. Observasi dilakukan dengan memilih perilaku hasil wawancara dengan guru. Termasuk kunjungan rumah, yang juga dilakukan observasi dan wawancara dengan orang tua/ wali subjek. 
Untuk memperkuat hasil asesmen, dilakukan beberapa tes psikologis. Dalam hal ini, tes yang digunakan dalam menegakkan diagnostik yaitu tes BINET dan tes grafis. Tes BINET merupakan salah satu dari bentuk tes intelegensi. Bentuk tes ini masih sangat sederhana dan disajikan secara berurutan sesuai dengan tingkat kesulitannya. Tes ini digunakan untuk anak umur 3 - 13 tahun. Hasilnya akan dapat mengetahui terkait kemampuan umum, kemampuan khusus, serta usia mental subjek. Hal-hal tersebut dianggap penting untuk diketahui guna ditindaklanjuti pada penanganan kasus.

Sedangkan tes grafis adalah jenis tes proyeksi non verbal yang mengutamakan performance subjek yang menghasilkan segala macam bentuk tulisan tangan, gambar atau lukisan yang dikerjakan dan dihasilkan seseorang atas dasar intensionalitas maupun akibat pengaruh ketidaksadaran terhadap dirinya. Adapun aspek yang dapat diungkap dalam tes grafis adalah kestabilan emosi, kemampuan bersosialisasi, dan kemampuan kognitif. Pada hakekatnya gambar adalah gerakan tangan yang diendapkan dan didokumentasikan melalui garis dan coretan. Dengan demikian, gambar terjadi sebagai akibat motorik tangan khususnya motorik halus. Gerakan tersebut dipengaruhi oleh kognisi, emosi, dan dorongan yang ada.

HTP (gambar rumah, pohon, dan orang) dipublikasikan pertama kali oleh J.N. Buck (1948) yang awalnya merupakan salah satu dari prosedur tes menggambar yang didesain secara khusus untuk mengukur penyesuaian kepribadian. ${ }^{8}$ Tes ini menggambarkan proyeksi diri tentang struktur kelemahan dan konflik motivasi seseorang yang menjadi dasar kesulitan dalam menyesuaikan diri.

\section{Intervensi}

Setelah diperoleh data, maka inilah perilaku yang diklasifikasikan akan dikurangi dan ditingkatkan. Adapun perilaku yang akan dikurangi yaitu (1) keluar dari bangku saat proses balajar-mengajar, (2) bersuara keras saat proses belajar-mengajar, dan (3) mendapatkan uang saat akan atau setelah melakukan hal yang baik. Sedangkan perilaku yang akan ditingkatkan yaitu (1) mengerjakan tugas secara mandiri dengan tuntas, (2) membawa buku sesuai jadwal, dan (3) melakukan sesuatu yang baik tanpa imbalan uang.

${ }^{8}$ Tri Daya Kisni dan Ni'matu Zahroh "Tes Grafis (HTP) Chromatic-Achromatic untuk Anak", 2005; UMM Press Malang. 
Langkah berikutnya akan dilakukan kontrol untuk membuat situasi yang mendukung proses perubahan, menetapkan tujuan, metode, dan siapa saja yang berperan dalam proses penyelesaian kasus. Situasi yang mendukung proses perubahan akan dibentuk baik di sekolahan maupun di rumah, guna mendukung intervensi yang akan dilakukan di sekolah dan juga di rumah.

Rancangan intervensi dalam kasus underachieverment pada YRW, yaitu: konseling individual, token ekonomi, aversif, dan positif parenting skill. Shertzer dan Stone (1982) merumuskan bimbingan sebagai suatu proses membantu orang untuk memahami dirinya dan lingkungan hidupnya. Diharapkan dengan proses ini akan menghasilkan pembentukan dan penjelasan tujuan dan nilai perilaku di masa datang.

YRW diajari strategi membangkitkan motivasi untuk mencari imbalan kepada dirinya sendiri. Nikmatnya kepuasan dan kebanggaan yang diperoleh jika mengerjakan PR atau tugas kelas dengan mandiri dan mempunyai pengetahuan yang lebih dari teman-teman yang lain. Dipupuk kesadaran etika dalam proses belajar mengajar, untuk meminimalkan perilaku (1) keluar dari bangku saat proses balajar-mengajar, (2) bersuara keras saat proses belajarmengajar, dan (3) mendapatkan uang saat akan atau setelah melakukan hal yang baik. Juga meningkatkan perilaku (1) mengerjakan tugas secara mandiri dengan tuntas, (2) membawa buku sesuai jadwal, dan (3) melakukan sesuatu yang baik tanpa imbalan uang.

Dalam proses konseling, subjek dibangun meningkatkan motivasi intrinsik dan ekstrinsik, mengajari cara belajar (study skills), manajemen waktu dan mengatasi kekurangannya dalam hal akademik. Dukungan yang besar dari berbagai pihak sangat dibutuhkan, termasuk mengkondisikan suasana belajar yang menyenangkan.

Modifikasi perilaku secara umum dapat diartikan sebagai hampir segala tindakan yang bertujuan untuk mengubah perilaku. Bootzin menyatakan bahwa modifikasi perilaku merupakan usaha untuk menerapkan prinsip belajar maupun prinsip psikologi hasil eksperimen yang lain pada perilaku manusia. Definisi lain diungkap oleh Eysenk bahwa modifikasi perilaku merupakan usaha mengubah perilaku dan emosi manusia dengan cara yang menguntungkan berdasarkan hukum teori modern proses belajar. Sedangkan Wolpe memberikan definisi modifikasi perilaku sebagai penerapan prinsip belajar yang telah teruji secara eksperimental untuk 
mengubah perilaku yang tidak adaptif. Kebiasaan yang tidak adaptif dilemahkan dan dihilangkan, perilaku adaptif ditimbulkan dan dikukuhkan.

Salah satu alatnya yaitu dengan token ekonomi. Prosedur ini diharapkan dapat mengurangi perilaku target. Program ini dilakukan dengan cara memberikan satu kepingan/ tanda (bintang) setiap kali perilaku sasaran sesuai pengkondisian. Bintang-bintang ini akan dapat ditukar dengan benda yang diinginkan subjek jika sudah memenuhi jumlah tertentu sesuai kesepakatan. Prosedurnya tidak berbeda dengan orang bekerja yang menerima upah setelah pekerjaannya selesai. Sistem token ekonomi ditujukan untuk meningkatkan perilaku adaptif dengan memungkinkan subjek untuk memperoleh token bila menunjukkan perilaku yang tepat, seperti berhasil tidak keluar dari bangku, berbicara keras saat proses belajar mengajar, membawa buku sesuai jadwal, mengerjakan tugas dengan mandiri dan tuntas. Akhirnya token yang telah terkumpul dengan jumlah tertentu tersebut dapat ditukar dengan hadiah yang diinginkan subjek.

Prosedur yang dijalankan yaitu dengan memberikan lembar "tabungan kepingan" bintang pada guru beserta "kepingan" bintangnya. Lembar tabungan yang dipegang guru akan ditempel didalam kelas untuk memberi motivasi anggota kelas melakukan perilaku yang diinginkan. Jika berhasil, maka kelas akan mendapatkan "kepingan" bintang berwarna biru. Lembar tabungan yang lain diberikan pada wali subjek dan ditempel di kamar. Jika subjek dapat memunculkan perilaku yang diinginkan, maka akan mendapatkan "kepingan" bintang berwarna kuning dari guru untuk ditempel di rumah. Kepingan yang terkumpul pada tabungan akan dihitung dan subjek ataupun anggota kelas bisa memilih hadiah jika telah mencapai jumlah tertentu dalam waktu satu minggu.

Untuk mendapatkan perubahan perilaku seketika, digunakan stimulasi aversif yang mana merupakan lawan dari stimulant penguatan, sesuatu yang tidak menyenangkan atau bahkan menyakitkan. Aversif merupakan suatu perilaku yang akan memperkecil kemungkinan diulanginya perilaku tersebut pada masa-masa selanjutnya. Definisi ini sekaligus menggambarkan bentuk pengkondisian yang dikenal dengan hukuman.

Penggunaan prosedur hukuman ini sering menimbulkan kontroversi. Prosedur hukuman adalah suatu prosedur yang umumnya dicadangkan untuk perilaku yang tidak adaptif. Dalam proses penangananya, prosedur hukuman memberikan stimulus yang mengikuti suatu perilaku mengurangi kemungkinan berulangnya perilaku tersebut. Keunggulan prosedur hukuman 
diantaranya yaitu: menghentikan dengan cepat, memudahkan diskriminasi perilaku yang harus dihilangkan oleh subjek, menjadi pelajaran bagi yang lain.

Sebelum benar-benar menerapkan prosedur ini, subjek dikondisikan agar tidak sampai mendapat hukuman dengan memberi peringatan, menyesuaikan tugas dengan kemampuan, dan memberi jalan keluar yang wajar bagi kebutuhan. Dalam prosesnya, telah dilakukan pembentukan tata tertib kelas yang mana juga ditetapkan hukuman yang akan diterima bagi pelanggar tata tertib pada poin-poin tertentu. Dalam memberikan hukuman, agar berpengaruh secara efektif maka pemberian hukuman dilakukan dengan memperhatikan beberapa hal, yaitu: menghalangi subjek menghindarkan diri dari hukuman, hukuman diberikan secara konsisten, dan dikombinasikan dengan prosedur lain, misalnya pemberian pemahaman, pujian, dan penghapusan.

Dalam pelaksanaannya, terlebih dahulu diadakan kesepakatan dengan seluruh anggota siswa. Adapun beberapa poinnya, yaitu:

$>$ Ditegur dengan memanggil nama dan menyuruhnya diam atau kembali ke tempat duduk, mengikuti KBM. Subjek dan seluruh kelas distimulasi untuk merasa malu melakukan kesalahan, hingga mendapatkan teguran.

$>$ Di "peringatkan" agar segera menyelesaikan tugasnya.

$>$ Bila memprovokasi teman yang lain "rame", maka akan dipindah tempat duduknya.

> Bila meninggalkan bangku, akan diambil bangkunya oleh teman yang lain ditaruh dipojok depan kelas dan ia diharuskan berdiri.

$>$ Bila tidak membawa buku sesuai jadwal atau tidak mengerjakan PR, maka harus meminta tanda tangan guru yang lain dan kepada madrasah.

$>$ Mengkomunikasikan dengan orangtua/ wali.

Pengarahan dan motivasi untuk tidak melanggar selalu diberikan disela-sela materi pelajaran. Agar, subjek dan siswa yang lain selalu ingat dan saling diingatkan oleh teman yang lain.

Intervensi terakhir adalah positif parenting skill. Dalam hal ini, bukan individu tapi keluarga yang menjadi unit penanganan. Positif parenting skill, yaitu pihak keluarga diberikan pemahaman mengenai pola asah, asih, dan asuh. Tujuannya, memberikan pemahaman keluarga tentang berbagai aspek nahaya jika anak terus menerus diberikan uang saku berlebih, juga 
membentuk jaringan hubungan antar sesama orang tua agar dapat saling mendukung dalam menghadapi masalah yang dialami, sehingga keluarga berfungsi lebih baik sebagai kesatuan. Terkadang, positif parenting skill mengadopsi pendekatan sistem untuk memahami kerja dari keluarga dan masalah yang muncul dalam keluarga. Dipandang dari perspektif sistem, positif parenting skill dapat memfokuskan untuk membantu anggota keluarga memahami hubungan mereka untuk memenuhi kebutuhan anak secara lebih adekuat. ${ }^{9}$ Program ini mengusahakan untuk membantu keluarga dalam menyikapi problem yang ada pada anggota keluarga. Dalam hal ini berkenaan dengan pengaruh masalah subjek di sekolah.

\section{Evaluasi Intervensi}

Dalam pelaksanaan intervensi konseling individual, YRW sangat senang dan bersemangat dalam proses konseling. Terjadi pola komunikasi yang baik dalam proses konseling dari awal hingga akhir. Setelah konseling YRW bersedia menjaga diri untuk tetap disiplin dan membatasi diri dalam bersikap. Akan lebih rajin dan patuh pada ibu guru di sekolah dan nenek di rumah. Namun, tetap harus diperhatikan adanya ketergantungan dari YRW pada konselor. YRW perlu untuk didampingi hingga ia benar-benar sudah bisa mandiri dan perubahannya tidak hanya bersifat "musiman". Selain itu, konselor harus hati-hati dalam memberikan perhatian pada YRW, mengingat YRW adalah anggota dari kelas reguler, yaitu IIIA. Kesan pilih kasih harus ditepiskan agar konseling dapat berjalan lancar dan tidak memunculkan permasalahan yang baru.

Dalam pelaksanaan intervensi token ekonomi, YRW kurang menghargai apa-apa yang ditawarkan dari metode ini. Sebab, YRW menganggap apapun yang ditawarkan, ia dapat membeli sendiri tanpa harus mengikuti aturan main. Itu artinya, token disini masih belum efektif. Namun, program ini sangat berpotensi bisa membantu dalam memberikan penguat untuk perilaku yang diharapkan dan pelemah untuk perilaku yang tidak diharapkan. Program ini juga bisa diterapkan dirumah, sebagai pengganti pemberian uang setiap YRW selesai atau akan melakukan sesuatu yang baik. Tentunya dengan memberikan pemahaman dan mendapatkan kesepakatan terlebih dahulu.

${ }^{9}$ Jeffrey S. Nevid, Spencer A. Rathus, Beverly Greene. 2005. "Psikologi Abnormal." PT Erlangga; Jakarta. 
Dalam pelaksanaannya, intervensi aversif sangat efektif. Sebab, dampaknya bisa langsung terlihat saat itu juga. Namun, tetap harus diperhatikan bahwa pengarahan dan motivasi untuk tidak melanggar harus selalu diberikan disela-sela proses belajar mengajar. Agar, YRW dan siswa yang lain selalu ingat dan saling diingatkan oleh teman yang lain untuk tidak melakukan pelanggaran.

Program intervensi positif parenting skill yang dilakukan ini mengusahakan untuk membantu keluarga dalam menyikapi problem yang ada pada anggota keluarga. Komunikasi berjalan baik dengan wali subjek, namun karena sebagian besar anggota keluarga merantau maka masih dirasa kurang menyeluruh. Butuh proses yang panjang untuk mengubah kebiasaan, terutama yang didasari atas alasan yang kuat. Merasa kurang intens dalam memberikan perhatian, membuat anggota keluarga memilih memberikan perhatian dengan caranya sendiri. Pihak keluarga dari ayah yang lebih memiliki ladang pekerjaan, berusaha memberikan lebih untuk meringankan pihak keluarga ibu agar tidak terbebani. YRW sering kali diingatkan untuk tidak meminta saku ke pihak keluarga ibu agar tidak merepotkan.

Program positif parenting skill ini belum maksimal, namun sudah dapat memberikan pemahaman pada keluarga. Karena sebagian besar anggota keluarga lebih sering diluar kota, belum semua anggota keluarga menjadi satu pemahaman. Wali YRW yang mana beliau adalah neneknya selalu mengeluarkan air mata jika mulai dibuka pembahasan tentang YRW. Sejak awal, anggota keluarga yang memberikan saku lebih sebagai bentuk perhatian pada YRW. Karena terbiasa, hingga kini YRW akan menuntut jika mendapatkan kurang dari biasanya, atau bahkan mengambil uang lain (misal tabungan) sebagai ganti uang sakunya. Keluarga juga selalu memberikan uang jika YRW akan atau telah melakukan sesuatu kegiatan positif. Hal ini bisa saja menjadi salah diartikan oleh YRW. Melihat kondisi ini, konseling yang intens dan pendampingan program untuk menyelesaikan masalah sangat dibutuhkan.

\section{Hasil}

YRW memiliki kapasitas intelegensi dalam kategori rata-rata atas. Hal tersebut menggambarkan kemampuannya berada pada taraf rata-rata atas anak seusianya. Sehingga, dapat diketahui bahwa YRW cukup mampu menyelesaikan tugas-tugas yang tanpa bimbingan orang lain. Dalam perkembangannya, YRW memiliki kemampuan motorik halus yang 
berkembang secara optimal. Aspek-aspek kemampuan khusus telah berkembang dengan baik, namun ada beberapa yang cukup dan rendah pada taraf perkembangan sesuai dengan usianya. Kemampuan khusus yang telah berkembang dengan baik adalah kemampuan visual-motor, arithmetic reasoning, dan vocabulary \& verbal fluency. Hal ini menandakan bahwa YRW mampu mengkoordinasikan penglihatan dan gerakan tangan. YRW telah mengenal konsep hitung dan perbendaharaan kata yang tepat dalam pengucapannya. Namun, kemampuannya pada aspek memory \& concentration dan judgement \& reasoning dalam kategori cukup. Hal ini menunjukkan bahwa YRW cukup mampu mengingat dan berkonsentrasi, serta cukup mampu memahami dan menalar sesuatu. Sedangkan kemampuan yang masih rendah ada pada aspek pengertian umum. Hal ini menunjukkan bahwa YRW belum mampu memahami hal-hal yang berlaku dilingkungannya. Itu juga dapat menjadi pendukung sikap YRW yang sekarang dipermasalahkan.

Tabel 2: Hasil tes BINET

\begin{tabular}{|l|l|}
\hline MA & $: 9$ tahun 4 bulan \\
\hline CA & $: 8$ tahun 8 bulan \\
\hline IQ & $: 115$ (rata-rata atas) \\
\hline Pengertian umum & $:$ rendah \\
Kemampuan visual-motor & $:$ baik \\
Arithmetic reasoning & $:$ baik \\
Memory \& concentration & $:$ sedang \\
Vocabulary \& verbal fluency & $:$ baik \\
Judgement \& reasoning & $:$ sedang \\
\hline
\end{tabular}

Piaget maupun Kohlberg sependapat bahwa orang tua mempunyai peran besar bagi pembentukan dan perkembangan moral seorang anak. Tanggung jawab orang tua untuk menanamkan nilai-nilai moral, etika, budi pekerti bahkan nilai religius sejak dini kepada anak-anaknya akan membekas didalam hati sanubarinya. ${ }^{10}$ YRW dalam masa perkembangan, dimana ia harus dibimbing untuk membentuk kepribadian yang baik. Situasinya yang diasuh oleh neneknya, dan bukan ayah dan ibu seperti teman-teman yang lain, membuat YRW merasa kurang akan kasih sayang. Untuk memenuhinya,

${ }^{10}$ Rida Nurhayanti. Dwi Novotasari, dan Natalia. Tipe Pola Asuh Orang Tua yang Berhubungan dengan Perilaku Bullying di SMA Kabupaten Semarang. Jurnal Keperawatan Jiwa. Volume 1. No. 1. Mei 2013; hal: 51. 
ia melakukan hal-hal yang mengundang perhatian orang di sekitarnya, termasuk menjadikan kelas gaduh saat di Madrasah.

John Locke mengibaratkan bahwa hati dan otak pada diri seorang anak masih berupa lembaran kertas kosong putih bersih. Lembaran itu masih bersifat murni, sehingga apapun yang terisi di atas lembaran itu sangat tergantung dari orang tua bagaimana ia menulis, mencoret, menggambar atau mewarnai, demikian pula pendidikan yang telah diterima sejak masa kanakkanak akan mempengaruhi pola pikir dan perilaku dalam diri anak (dalam Dariyo, 2004). ${ }^{11}$ Keluarga adalah yang pertama kali mengisi lembaran kosong tersebut. Semua anak, baik yang dilahirkan dari keluarga bercerai atau tidak sama-sama berasal dari fitrah (dalam Islam) atau bagai kertas kosong. Maka keluarga yang memiliki kesempatan pertama untuk mengisi kertas tersebut, memberikan pola asuh yang baik dan penjelasan yang sesuai dengan anak agar anak menjadi kuat dan tabah dalam menerima, atau dilatih untuk menjadi pribadi tangguh.

Namun, dengan kebiasaannya memegang uang banyak sebagai uang saku atau hadiah karena akan atau talah melakukan hal yang baik, yang jumlahnya lebih banyak dari teman-temannya, YRW merasa bisa mendapatkan apa yang ia inginkan. Masing-masing keluarga dari ayah dan ibu memberikan jatah saku kepada YRW, dengan jumlah total saku YRW setiap harinya \pm Rp. 10.000,- yang diberikan bertahap dari berangkat sekolah, pulang sekolah, berangkat les, hingga malam. Jumlah saku tersebut belum termasuk saku diluar rutinitas, semuanya selalu habis dalam satu hari.

Pada usianya sekarang, kebutuhan yang berkaitan dengan uang hanya untuk membeli jajanan atau mainan. Faktanya, jika YRW menginginkan mainan, maka dengan segera dipenuhi oleh keluarganya. Hal demikian membuat YRW kurang menghargai apa-apa yang dijadikan reward oleh guru dan orang lain jika ia melakukan hal-hal positif, termasuk kegiatan belajar mengajar. Sehingga, dorongan untuk berprestasi kurang dan cenderung melakukan hal-hal sesuai keinginanya.

Seperti yang diungkapkan oleh wali kelasnya, bahwa YRW dikenal sebagai siswa yang tidak bisa diam, suka keluar dari kursi dan berbicara keras di dalam kelas. Sering kali YRW menjadi provokator anggota kelas lain menjadi gaduh. YRW termasuk lambat dalam mengerjakan tugas kelas, sering tidak mengerjakan PR dan suka mencontek anggota kelas yang lain

\section{${ }^{11}$ Ibid.}


jika ada ujian kelas atau mengerjakan tugas kelas. Banyak tugas-tugas yang tertinggal dari anggota kelas yang lain dan sering kali mendapatkan nilai yang dibawah rata-rata. Terkesan YRW mencari perhatian, sebab jika mendapatkan perhatian penuh seperti pendampingan dalam mengerjakan tugas maka tugas akan lebih cepat diselesaikan. Namun, guru merasa tidak bisa memberikan perhatian hanya kepada YRW saja, sebab yang diajar didalam kelas juga ada anggota kelas yang lain.

\section{Kesimpulan}

Dari hasil asesmen, diperoleh berbagai data yang dapat memperkuat pengambilan diagnosis. Permasalahan dari YRW yaitu nilai prestasinya yang rendah. Dalam proses belajar mengajar, YRW cenderung tidak bisa dikendalikan dan melakukan hal-hal sesuai dengan keinginanya. Beberapa hal yang menjadi pencetus perilaku yang dipermasalahkan, diantaranya yaitu: situasi YRW yang merupakan anak dari keluarga yang bercerai, ketidakhadiran figur ayah dan ibu dalam kesehariannya membuat YRW mencari perhatian dalam bentuk yang berbeda (pelampiasan di sekolah), keberadaan neneknya yang selalu berusaha memenuhi keinginan YRW membuatnya kurang memiliki kerja keras dan cenderung meremehkan. Hasil raport di sini tidak bisa menjadi tolak ukur nilai, sebab kepala madrasah mempunyai kebijakan sendiri untuk memberikan batas minimum pemberian nilai pada siswa. Akibatnya, YRW hanya menjalani aktifitas tanpa adanya greget untuk berprestasi dan membuat guru kualangan dalam mengambil sikap terhadapnya. Fakta tersebut diatas tidak sejalan dengan penemuan bahwa YRW memiliki IQ rata-rata atas. Itu artinya, potensi YRW tinggi namun prestasi belajarnya rendah. Hal tersebut disebut juga dengan underachievers.

Tabel 3: Distribusi IQ

\begin{tabular}{|c|c|}
\hline IQ & KLASIFIKASI \\
\hline$>130$ & Sangat Superior \\
\hline $120-129$ & Superior \\
\hline $110-119$ & Rata-rata Tinggi \\
\hline $90-109$ & Rata-rata \\
\hline $80-89$ & Rata-rata Rendah \\
\hline $70-79$ & Batas Lemah Mental \\
\hline$\leq 69$ & Lemah Mental \\
\hline
\end{tabular}


Sumber: Walgito, 1992: 152

Berdasarkan penilaian sistem belajar tuntas, maka siswa dikatakan lulus jika memperoleh nilai misalkan 6 pada skala 0-10 atau 60 pada skala 0 100. Siswa berbakat akademik seharusnya tidak cukup hanya memperoleh nilai minimal kelulusan. Mereka hendaknya mampu berprestasi sesuai dengan tingkat IQ yang tinggi. Perbandingan prestasi siswa dengan hasil tes IQ digunakan untuk mengidentifikasi underachiever.

Tabel 4: Contoh Pedoman Pengkategorian Underachiever

\begin{tabular}{|c|c|c|c|}
\hline NO & IQ & KLASIFIKASI & PRESTASI MINIMAL \\
\hline 1 & $>130$ & Sangat Superior & 9 \\
\hline 2 & $120-129$ & Superior & 8 \\
\hline 3 & $110-119$ & Rata-rata Tinggi & 6 \\
\hline 4 & $90-109$ & Rata-rata & \\
\hline 5 & $80-89$ & Rata-rata Rendah & \\
\hline 6 & $70-79$ & Batas Lemah Mental & \\
\hline 7 & $\leq 69$ & Lemah Mental & \\
\hline
\end{tabular}

Penanganan dirasa masih harus dilanjutkan guna mendapatkan hasil yang maksimal. YRW yang memiliki potensi intelegensi dalam kategori ratarata atas ini, tidak sesuai dengan prestasi belajarnya yang rendah. Diharapkan setelah ini YRW bisa menyeimbangkan antara potensi kecerdasan yang dimiliki dengan prestasi belajar yang diraihnya. Untuk itu, perilaku yang menghalangi atau menjadi sebab tidak terpenuhinya harapan tersebut harus diminimalkan.

\section{Saran}

Untuk mendapatkan hasil yang maksimal, perlu adanya dukungan dan partisipasi yang baik dari berbagai pihak. Selain YRW sendiri, termasuk pihak madrasah, dan pihak keluarga. Adapun beberapa saran yang dapat kami berikan dalam penanganan kasus ini, yaitu:

\section{Untuk Pihak Sekolah}

$>$ Guru Bimbingan dan Konseling (BK) dapat memberikan bantuan layanan konseling kepada YRW secara berkala, guna pendampingan di sekolah. Termasuk pendampingan kepribadian. Sehingga, kebutuhan akan perhatian bagi YRW terpenuhi guna meminimalkan cara mencari perhatian yang keliru.

$>$ Guru BK dan guru kelas dapat mengkomunikasikan perkembangan YRW dengan orangtua/ wali. Jika diperlukan, memberikan 
rekomendasi untuk minta bantuan psikolog atau ahli guna menuntaskan hingga pada penyebab permasalahan (termasuk masalah uang saku yang berlebihan dan pola asuh keluarga).

$>$ Mengupayakan memunculkan perilaku yang diharapkan. Guru kelas bisa mengaktifkan program token, dan memberikan penjelasan pada manfaat, nilai kebanggaan dan penghargaan yang akan diperoleh. Program ini bisa dilaksanakan dengan menjalin kerjasama bersama orang tua/ wali (hasil perolehan token akan di simpan di rumah).

\section{Untuk Pihak Keluarga}

Mencari bantuan konseling untuk anak dan seluruh keluarga jika perlu. Jika seluruh keluarga ikut terlibat konseling, diharapkan perubahan dapat lebih cepat terjadi karena dukungan dari seluruh keluarga. Perubahan perilaku bukan hanya dari anak tetapi juga perubahan perlakuan anggota keluarga yang lain terhadap anak.

$>$ Mengupayakan penghapusan (extinction) pada kebiasaan yang dianggap kurang tepat. Yaitu dengan menghentikan pemberian uang ketika YRW selesai atau akan melakukan sesuatu. Sebaiknya hal ini dihentikan atau dialihkan pada pemberian pengukuh yang lain (misalnya token ekonomi).

$>$ Hendaknya keluarga memberikan contoh kerja keras sebagai kunci sukses, dengan usaha individual, motivasi dari dalam diri, komitmen dan kepercayaan diri sebagai resep keberhasilan. 


\section{DAFTAR PUSTAKA}

Angelia P.W.N. 2013. Meningkatkan Disiplin Belajar di Kelas Melalui Metode Reward Berjenjang dan Konsekuensi Logis. SDK BPK PENABUR Bintaro Jakarta. Jurnal Pendidikan Penabur - No.21/Tahun ke12/Desember 2013.

Bangun A.N.C dan Abdul H.S. Pengaruh Perhatian Orang Tua, Sikap Disiplin Belajar Siswa dan Kreativitas Siswa terhadap Prestasi Belajar Siswa Kelas XII Program Studi Keahlian Teknik Elektronika di SMK Negeri 3 Yogyakarta Tahun Ajaran 2012/2013. Program Studi Pendidikan Teknik Elektronika, Fakultas Teknik, Universitas Negeri Yogyakarta.

Fakultas Psikologi Universitas Gunadarma. 2013. Faktor Yang Mempengaruhi Pelanggaran Disiplin Siswa Dan Implikasinya Terhadap Layanan Bimbingan \& Konseling. Jurusan Bimbingan dan Konseling FIP UNP. KONSELOR. Jurnal Ilmiah Konseling. Volume 2 Nomor 2 Juni 2013. hlm. 20-25.

Jeffrey S. Nevid, Spencer A. Rathus, Beverly Greene. 2005. "Psikologi Abnormal.” PT Erlangga; Jakarta.

Munandar. 2009. Pengembangan kreativitas anak berbakat. Jakarta: Rineka Cipta.

Nur Cahyani Desi Widowati. 2013. Hubungan Antara Pola Asuh Orang Tua, Motivasi Belajar, Kedewasaan dan Kedisiplinan Siswa dengan Prestasi Belajar Sosiologi Siswa Kelas XI SMA Negeri 1 Sidoharjo Wonogiri. Jurnal Penelitian. Fakultas Keguruan dan Ilmu Pendidikan Universitas Sebelas Maret Surakarta.

Peter Garlans Sina. 2013. Money Belief Penentu Financial Behavior. Alumni Universitas Kristen Satya Wacana. Jurnal Economia. Volume 9, Nomor 1, April 2013.

Rida Nurhayanti. Dwi Novotasari, dan Natalia. Tipe Pola Asuh Orang Tua yang Berhubungan dengan Perilaku Bullying di SMA Kabupaten Semarang. Jurnal Keperawatan Jiwa. Volume 1. No. 1. Mei 2013; hal: 51.

Ridho Illahi, Syahniar, Indra Ibrahim. Faktor yang Mempengaruhi Pelanggaran Disiplin Siswa dan Implementasinya Terhadap Layanan 
Bimbingan dan Konseling. Konselor, Jurnal Ilmiah Konseling. Volume 2, Nomor 2, Juni 2013.Hal.20

Supratiknya dan Titik Kristiyani. Efektifitas Metode Problem-Based Learning dalam Pembelajaran Mata Kuliah Teori Psikologi Kepribadian II. Jurnal Psikologi. Volume 33, No.1, ISSN: 0215-8884. Fakultas Psikologi Universitas Gadjah Mada. Hal: 1

Tri Daya Kisni dan Ni'matu Zahroh "Tes Grafis (HTP) ChromaticAchromatic untuk Anak", 2005; UMM Press Malang.

Wisnu S.H dan Arizka D.P. Faktor-Faktor Pembentuk Kepribadian Matang Pada Dewasa Awal Yang Mengalami Perceraian Orangtua. Fakultas Psikologi UMS.

Zainul Anwar. 2013. Analisis Underchiever pada Siswa Akselerasi. Fakultas Psikologi Universitas Muhammadiyah Malang. Jurnal Online Psikologi. Vol.01 No.01, Tahun 2013. ISSN: 2301-8259. 